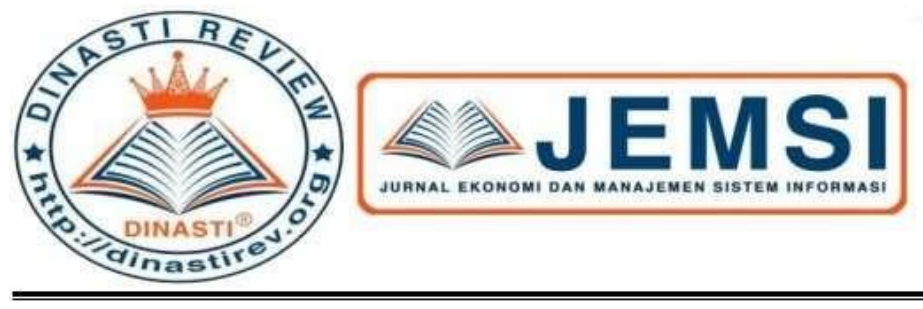

\title{
IMPLEMENTASI BUSINESS ETHIC PADA PT BANK SAHABAT SAMPOERNA (BSS) tbk
}

Agung Pamuji

Universitas Mercu Buana, Jakarta, Indonesia

ARTICLE INFORMATION

Received: 28 April 2020

Revised: 18 Juni 2020

Issued: 7 Juli 2020

Corresponding author: first author

E-mail:

gung.pamuji@gmail.com

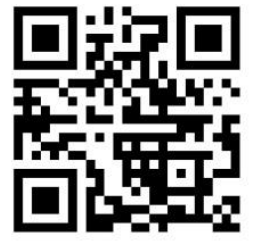

DOI:10.31933/JEMSI
Abstrak: Penelitian ini mempunyai tujuan untuk mengetahui Etika bisnis yang terdapat dalam suatu perusahaan. Perusahaan yang menjadi objek penelitian adalah PT Bank Sahabat Sampoerna (BSS) tbk. Penelitian ini menggunakan cara deskriptif kualitatif dengan studi literature yang berkaitan dengan etika bisnis, Informasi didapatkan dari artikel, modul dan internet. Disamping itu berdasarkan pengalaman empiris serta pengamatan langsung pada objek penelitian pada PT Bank Sahabat Sampoerna. Hasil penelitian yang didapat yakni, dalam Perusahaan PT Bank Sahabat Smapoerna (BSS) tbk telah menjalani prinsip etika. Dalam hal ini bisa dilihat dengan pelayanan yang baik dan ramah terhadap nasabah, melindungi kerahasiaan nasabah, menjamin keamanan dan kenyamanan nasabah. Serta terbukti dengan adanya informasi umum mengenai profil, visi, dan misi serta laporan keuangan perusahaan yang telah terpublish baik di website perusahaan tersebut.

Kata Kunci: Business Ethics, Kode etik

\section{PENDAHULUAN \\ Profil Perusahaan}

Seiring dengan pertumbuhan ekonomi di dunia perbankan, pegelolaan yang baik dengan berlandaskan etika perlu dilakukan setiap pegawai ataupun karyawan. Hal ini agar berjalannya bisnis yang yang baik dan adil khususnya di sektor swasta. Good governance merupakan salah satu konsep yang dapat menjadi panduan dalam menjalankan peroses pelaksanaan di perusahaan. Keberhasilan Good governance, khususnya Good corporate governance, memiliki kaitannya dengan implementasi bisnis etik yang dijalankan oleh perusahaan.

Awal mulanya Bank Sampoerna ini mengambil alih dari bank Dipo Internasional yang didirikan tanggal 27 September 1990. Bank mulai beroperasi pada tanggal 9 Septembe 1991 sesuai izin usaha yang diberikan Menteri Keuangan Republik Indonesia.

Lalu ditahun 1997 terjadi perubahan nama dari Bank Dipo Internasional ke Bank Sampoerna.Fberuari 2008 PT PahalamasSejahtera yang menjadi pemegang saham Bank Dipo Internasional menyetujui dan menandatangani perjanjian pembeliandan penjualan dengan sampoerna grup.

Pada bulan mei 2008 terjadi rapat umum luar biasa yang dihadiri oleh seluruh jajaran 
pemegang saham. Terjadi perubahan modal dan anggaran dasar untuk bank sampoerna tsb yaitu menjadi 400 milliar. Dan perubahan tersebut juga disetujui oleh Menteri Hukum negara Indonesia.

Ditahun tersebut pada tahun 2008, telah terjadi krisisfinancial global dan adanya proses akuisisi. Lalu Sampoerna Group berfikiran untuk membantu semua pengusaha kelas menengah dengan membuat dan membangun bisnis baru di bidang keuangan, yaitu membuat koperasi yang bernama KoperasiMitra Sejati atau sering disebut (Sahabat UKM).

Mulai saat itu pertumbuhan dan perkembangan sahabat UKM ini bertumbuh sangat pesat. Sahabat UKM mampu bersaing dengan beberapa lembaga keuangaan. 5 tahun berikutnya Sahabat UKM ini terjadi perubahan nama yang awalnya sahabat UKM menjadi KSP Sahabat Mitra Sejati. KSP Sahabat sampai saatn ini sudah memiliki banyak kantor cabang, mungkin hamper 150an yang tersebar di seluruh Indonesia.

Setelah terjadinya krisiis finansial global ditahun 2010, proses akuisisi terhadap Bank Dipo Internasional dilanjutkan. Bersamaan dengan itu secara paralel juga telah dilakukan perubahan pihak yang mengakuisi saham Bank dari Orient Distribution Network Pte. Ltd. kepada PT Sampoerna Investama. Pada bulanMei 2011 tersebutproses akuisisi dari bank Dipo ke Bank Sampoerna telah selesai.

\section{Perubahan Nama Bank}

Pada bulan Desember tahun 2011 terjadi perubahan nama perseroan yang awalnya Bank Dipo menjadi PT Bank Sahabat Sampoerna tbk, perubahan pada logo bank pun ikut berubah menjadi logo Sampoerna Group. Lalu di tahun 2012 perubahan disetuji oleh Menteri dan Bank Indonesia (BI). Sampai saatn ini BSS telah memiliki 20-an cabang yang tersebar di beberapa kota di seluruh Indonesia.

\section{Visi dan Misi Perusahaan \\ Visi}

Menjadi institusi keuangan pilihan masyarakat yang berfokus pada sektor usaha mikro, kecil dan menengah dan memberikan pelayanan yang terpercaya dan profesional.

Misi

Memberdayakan masyarakat dengan memberikan kesempatan dan dukungan agar berhasil di sektor usaha mikro, kecil dan menengah.

Etika bisnis di akan berjalan sesuai dengan visi dan misi diatas, kode etik juga harus dipahami dan dijalankan sebagai landasan moral, sikap, dan perilaku pegawai. Setiap pimpinan wajib menjadi acuan untuk pegawai lainnya dalam implementasi penerapan kode etik tersebut.

\section{KAJIAN PUSTAKA \\ Business Ethics}

Etika merupakan nilai dan norma yang mengatur perilaku manusia. Etika bisa membuat dan membentuk karakter menjadi baik karena setiap waktu pegawai akan menjalankan nilai/norma yang baik, hal iniakan membawa dampak positif untuk hubungan Bank dengan pelanggan (nasabah). Etika menjadi standar bagi penerapan prinsip moral dasar dalam setiap aspek/bidang kehidupan masyarakat, contohnya adalah etika bisnis. Sternberg (1994) dalam Lukviarman (2004), etika bisnis sebagai suatu bidang filosofi yang berhubungan dengan pengaplikasian ethical reasoning terhadap berbagai perihal praktek dan aktivitas dalam bisnis. Etika dalam bahasa Yunani ialah ethos Keraf (1998) mengemukakan etika adalah adat istiadat atau kebiasaan yang akan membentuk aturan kuat di masyarakat, serta cara yang dilakukan 
mengikuti norma yang ada, dan norma tersebut membentuk sifat masyarakat dalam menghargai adat istiadat. Pengertian moral menurut Velasquez (2005) bahwa moral dapat mempengaruhi seseorang dalam memutuskan keputusan. Maka pengertian etika dan moralitas berbeda, etika ialah cabang filsafat yang menjelaskan tentang nilai dan norma moral yang menentukan perilaku manusia dalam hidupnya.

Menurut (Hartman. 2008) Etika bisnis memiliki lima teori/pendekatan/model untuk mengambil keputusan, diantaranya :

a. Utilitarian model, Suatu model yang menekankan kepada manfaat dan tujuan bagi kepentingan orang banyak.

b. Deontological, Etika Deontologi menekankan kewajiban manusia untuk bertindak secara baik telepas dari tujuan atau akibat dari tindakan itu.

c. Moral rights model, Model ini membimbing manusia untuk mengeksplorasi prinsipprinsip moral yang terkait dengan keputusan, atau yang dikenal dengan hak.

d. Virtue ethics Suatu model yang mengarahkan manusia untuk mempertimbangkan karakter moral individu dan beraneka ragamnya sifat karakter yang dapat berkontribusi, atau menghalangi makna kehidupan.

e. Justice model, Model ini memberikan wawasan/pengetahuan tentang proses pengambilan keputusan, sebuah teori yang didasarkan pada keadilan sebagai prinsip sosial utamanya.

Menurut Amran (2011) bahwa etika bisnis memiliki peranan yang lebih dibandingkan hukum, sebagai berikut:

- Hukum sebagai salah satu sarana atau alat pengawasan (social control) yang paling efektif untuk mengendalikan praktek bisnis yang tidak sehat. Karena hukum menetapkan secara tegas apa yang seharusnya dilakukan serta yang tidak boleh dilakukan, serta bentuknya yang tertulis dapat memberi rasa aman bagi para pelaku bisnis, karena apabila terjadi pelanggaran sanksinya jelas.

- Bisnis tidak bisa lepas dari faktor hukum, Bahkan pada taraf normatif, etika mendahului hukum. Adalah sebuah keharusan bisnis mematuhi hukum yang berlaku.

- Etika bisnis mendasari terbentuknya hukum (substantif) bukan sebaliknya hukum yang membentuk etika bisnis. Etika sebagai bagian/cabang dari filafat (umum) yang mempelajari tentang tindakan manusia mengenai selayaknya bersikap dimasyarakat.

- Filsafat hukum mempelajari tentang hakekat hukum, juga merupakan cabang filsafat (khusus). Keduanya (etika dan filsafat) yang pada dasarnya mengatur tinngkah laku manusia dalam bersosialisasi.

- Etika berhubungan dengan apa yang seharusnya dilakukan dan tidak boleh dilakukan, sedangkan hukum cenderung ditafsirkan sebagai masalah legal atau ilegal.

- Tidak semua etika diatur sepenuhnya oleh hukum, karena etika terus berkembang dalam kehidupan masyarakat yang mencerminkan pemikiran etis masyarakat dalam membangun etika bisnis, sedangkan hukum bersifat terbatas. 
- Namun demikian hukum harus dapat mengkodifikasikan harapan dari etika, meskipun disadari bahwa tidak semua harapan etika tersebut dapat dipenuhi seluruhnya oleh hukum.

Teori - teori tersebut dibutuhkan jika individu/manusia akan dihadapkan dengan dilema etika atau proses pembuatan keputusan. Pembuatan keputusan dilakukan berdasarkan analisys stakeholders yang meliputi pemegang saham, aktivis, pemerintah, kreditor, pemberi pinjaman, karyawan, pelanggan, pemasok, dan lain-lain (Sakinatantri, 2013). Masing-masing teori memiliki kekurangan atau kelebihan tersendiri. Hal ini dikarenakan perilaku etis antara manusia yang satu dengan yang lain memiliki tujuan yang berbeda. Implementasi etika bisnis dapat didasarkan oleh satu teori atau melakukan kombinasi dari teori-teori tersebut. Hal terpenting dari penerapan teori ini adalah penerapannya tidak keluar dari dasar negara Indonesia, yakni Pancasila.

\section{Manfaat Etika Bisnis}

Perilaku Etis penting diperlukan untuk sukses jangka panjang dalam sebuah bisnis. Maka, bisnis sering menetapkan beberapa pilihan strategi berdasar nilai dimana pilihan tersebut di dasarkan atas keuntungan, kemaujuan, dan kelangsungan hidup perusahaan.

Menurut (Muslich, 2004), Manfaat etika bisnis untuk kelangsungan perusahaan adalah sebagai berikut:

1). Perusahaan menjadi tepercaya oleh pelanggan.

2). Perusahaan memiliki citra yang baik.

3). Perusahaan memiliki budaya sendiri.

4). Perusahaan memperhatikan kepentingan bersama.

5). Perusahaan merasa nyaman.

6). Perusahaan dapat mengurangi Biaya.

7). Perusahaan dapat memaksimalkan keuntungan.

8). Perusahaan dapat mencegah terjadinya kerugian.

9). Perusahaan menjunjung nilai moral.

10). Perusahaan memiliki motivasi bekerja yang baik.

11).Perusahaan akan mampu mengembangkan jati diri.

12).Perusahaan memiliki pengendalian diri.

13).Akan tercipta persaingan yang sehat.

14).Akan tercipta saling percaya yang kuat.

15).Akan tercipta atmosfer kerja yang baik.

16).Akan tercipta hubungan yang harmonis.

\section{Corporate Culture}

Cara pandang perusahaan berdasarkan pada nilai dan keyakinan yang tertuang dalam budaya perusahaan (Corporate Culture). Menurut Robbins, budaya perusahaan adalah sekumpulan sistem nilai yang diakui dan dibuat oleh semua anggotanya yang membedakan Perusahaan yang satu dengan yang lainnya (Ali, 2017). Budaya Perusahaan memiliki 7 elemen di antaranya:

1. Struktur yang hirarki 
2. Tempo pekerjaan

3. Pendekatan terhadap humor

4. Metode penyelesaian masalah

5. Lingkungan persaingan

6. Insentif

7. Otonomi individu

Lowney (2005), menunjukkan bahwa nilai budaya organisasi sangat berpengaruh motivasi para anggota dalam bekerja, seseorang dapat menjalankan fungsinya secara efektif dalam suatu organisasi/perusahaan, seseorang perlu tahu bagaimana mengerjakan atau harus mengerjakan sesuatu, termasuk bagaimana berperilaku sebagai anggota organisasi, khususnya dalam lingkungan organisasinya (Widuri dan Paramita, 2007).

Selain itu, budaya perusahaan ada kaitan dengan manajemen pada level corporate. Peraturan yang mengatur tentang corporate di Indonesia (Perseroan Terbatas/PT) adalah UU No. 40 tahun 2007. PT di Indonesia kemudian diwajibkan memiliki 3 organ, yaitu (Rapat Umum Pemegang Saham (RUPS), Direksi dan Dewan Komisaris).

RUPS adalah organisasi tertinggi yang mempunyai hak dan wewenang yang tidak dimiliki oleh organ lainnya. Lalu, Direksi (BOD) yaitu Organisasi Perseroan yang memiliki kewenangan dan bertanggung jawab penuh atas pengurusan Perseroan untuk kepentingan perseroan. Yang terakhir adalah Dewan Komisaris yangmerupakan organisasi Perseroan yang melakukan pengawasan secara umum dan/atau khusus serta memberi nasihat kepada Direksi (Kurniawan, 2014).

\section{METODE PENELITIAN}

Perolehan data yang digunakan dalam tugas ini menggunakan metode pengumpulan data berupa studi literature dari buku refrensi, jurnal ilmiah, dan media lainnya untuk memahami metode dan konsep. Selain itu, penelusuran website corporate dilakukan untuk mengetahui lebih detail.

Hidayat (2010), mengemukakan bahwa penelitian deskriptif adalah penelitian yang sangat luas dalam penggunaan data-datanya. Luas disini yaitu luas lebih condong pada analisa yang sifatnya panjang dari awal penelitian sampai akhi penelitian, penyelesaian dalam penelitian deskriptif inilah membuat seseorang harus memiliki komitmen yang kuat dari teori sampai ketika terjun di lapangan.

\section{HASIL DAN PEMBAHASAN Etika Bisnis dan Kode Etik}

Bank Sampoerna yang bergerak di bidang industri perbankan dan jasa keuangan menyadari bahwa aspek kepercayaan dari pemegang saham dan para nasabahnya merupakan hal yang esensial dalam mendukung pertumbuhan kinerja Bank Sampoerna yang sehat dan stabil. Karenanya Bank Sampoerna memandang perlu menerapkan etika bisnis pada setiap tingkatan organisasi dan pada setiap aktivitas operasional perusahaan serta menetapkan etika perusahaan dalam melakukan aktivitas usahanya yang menggambarkan sikap moral Bank Sampoerna. Agar sikap moral tersebut dapat benar-benar diimplementasikan dalam setiap aktivitas usaha, maka perusahaan harus merumuskan etika berbisnis/berusaha yang disepakati bersama. Kode Etik inilah yang akan menjadi tolak ukur setiap perilaku karyawan maupun pegawai dalam menjalankan aktivitas operasional. Bank Sampoerna ini memiliki panduan kode etik atau Code of Conduct (CoC) sebagai pedoman etika bisnis yang akan menjadi prinsip atau landasan/dasar yang menjadi acuan hubungan di antara manajemen dan karyawan/pegawai Bank Sampoerna dan hubungan dengan para pemangku kepentingan dalam berbisnis, yang diharapkan akan 
mendukung implementasi di perusahaan.

Terdapat 11 Kode Etik Bank Sampoerna yang antara lain berisi:

1. Nilai-nilai Perusahaan

2. Budaya Kepatuhan

3. Anti Fraud / Anti Suap / Anti Korupsi

4. Miss Selling / Miss Represent Produk dan Jasa

5. Mencegah Pencucian Uang

6. Menghindari Benturan Kepentingan

7. Menjaga Kerahasiaan dan Perlindungan Data

8. Menghindari Berkompromi Karena Hadiah / Hiburan

9. Cepat dan Tanggap Menangani Keluhan Nasabah

10. Berani Bicara (Speak up)

11. Penggunaan Fasilitas Kantor

\section{Kepatuhan Kode Etik}

Seluruh jajaran wajib mematuhi pedoman Code of Conduct sebagai pedoman berperilaku, baik di dalam maupun di luar lingkungan Bank yang membawa citra Bank dengan penuh tanggung jawab. Pengenaan sanksi atas pelanggaran/ketidakpatuhan terhadap Code of Conduct mengacu pada peraturan kepegawaian yang berlaku.

\section{Penyebaran Kode Etik}

Penyebaran Kode Etik dilakukan dengan memanfaatkan berbagai media dan kesempatan internal event kepada seluruh karyawan dan karyawati Bank Sampoerna pada segala tingkatan termasuk tenaga outsourcing. Media penyebaran Kode Etik Bank Sampoerna antara lain dilakukan melalui:

1. Majalah Internal

2. SMS Broadcast

3. Surat Edaran

4. Briefing dan Doa Pagi

5. Corporatme Mail

6. Social Site Network

Seluruh karyawan dan karyawati juga menandatangani kontrak kerja yang salah satunya adalah pernyataaan kepatuhan terhadap Kode Etik dan dijadikan sebagai salah satu bagian dalam penilaian karyawan (kondite) yang dilaksanakan setiap tahun. Strategi dan implementasi penyebaran Kode Etik dilakukan melalui pembentukan Change Agent yang diharapkan menjadi role model bagi seluruh karyawan dan karyawati Bank Sampoerna.

\section{Jenis sanksi Kode Etik}

Pegawai yang melakukan pelanggaran sanksi disiplin dikenakan sanksi antara lain:

1. Sanksi jenis pelanggaran disiplin ringan:

a. Surat Teguran Satu (ST 1

b. Surat Teguran Dua (ST 2)

2. Sanksi jenis pelanggaran disiplin sedang: 

a. Surat Pelanggaran Satu (SP 1)
b. Surat Pelanggaran Dua (SP 2)
c. Surat Pelanggaran Tigas (SP 3)

3. Sanksi jenis pelanggaran disiplin berat:

Pemberhentian/Pemutusan Hubungan Kerja (PHK)

\section{Corporate Culture}

The Sampoerna Way

The Sampoerna Way adalah konsep nilai yang disusun dengan tujuan untuk memberikan pedoman bagi setiap pihak dalam berkarya di organisasi yang telah didirikan sejak 1913 . Pedoman tersebut merupakan identitas atau jati diri dari bank sampoerna yang akan membentuk karakter perusahaan. Untuk mengembankan bisnisnya Bank Sampoerna yakini bahwa setiap karyawan/pegawainya adalah sumber daya yang utama. Bisnis yang semakin ketat dan persaingan yang hebat sangat membutuhkan manusia dengan karakter atau pribadi yang kuat sebagai leader, sehingga dengn memounyai karakter yang kuat perusahaan akan memenangkan dan mencapai tujuannya dan membawa perusahaan ini terus bertumbuh dan berkembang dengan pesat di masa yang akan dating.

Identitas yang dituangkan ke dalam core values (nilai inti) ini bermanfaat untuk Menuntun dalam menentukan tindakan yang tepat,menyatakan nilai-nilai yang harus dijalankan dengan penuh komitmen, memberikan batasan-batasan dalam mengatur diri sendiri, dan mendukung dalam mencapai visi dan mempertahankan kelanjutan organisasi. The Sampoerna Way berisi nilai inti yang terbagi dalam filosofi yang menjadi pedoman bagi setiap karyawan, sebagai berikut:

\section{Towards Excellence (Anggarda Paramita)}

Anggarda Paramita dalam bahasa Sansekerta adalah "Menuju Kesempurnaan", yang bisa diartikan usaha yang akan terus menerus dilakukan untuk menjadi yang. Atau bisa diartikan juga perjuangan yang tdiak kenal lelah dan tidak putus asa demi mencapai kesempurnaan, yang secara integral terkait dengan semua aspek dalam organisasi.

Filosofi pertama ini terdiri dari 2 nilai inti, yaitu:

1. Meritocratic System (Apresiasi terhadap hasil karya / prestasi dan kontribusi) Meritocratic System atau Sistem yang basis Prestasi adalah sistem ini memberikan penghargaan untuk para individu(karyawan) sesuai dengan kompetensi dan prestasi mereka sehingga tercapai tujuan (kesempurnaan) organisasi. Dalam bisnis, sistem ini mengutamakan kinerja dan kompetensi individu(karyawan) dalam organisasi demi tercapainya tujuan bersama. Adapun karakteristik Meritocratic System adalah:

- Individu dinilai secara adil berdasarkan kinerja dan kontribusinya

- Keinginan kuat untuk melakukan yang terbaik

- Kerendahan hati untuk belajar dari orang lain ("Malu bukan karena tidak tahu tetapi malu karena tidak mau belajar"); menghindari sikap tempramental

- Mampu menyeimbangkan antara rencana strategis dengan rencana pelaksanaan yang rinci

- Berorientasi pada kinerja; memastikan pelaksanaan tepat waktu dan hasil yang memuaskan

- Tidak memiliki sikap egoisme

- Disiplin dan fokus, memberikan kesempatan bagi setiap karyawan untuk mengoptimalkan potensi dan menyumbangkan aspirasi 
- Penunjukan berdasarkan kinerja, potensi kemampuan, komitmen serta pengetahuan

2. Requisite Organization (Pengelolaan sistematau cara kerja yang terencana dan terkontrol dengan baik)

Nilai inti ini diadaptasi dari buku "Requisite Organization" oleh Jacque Elliots, yang menerangkan bahwa organisasi itu harus dapat membuat kondisi dimana setiap pihak dapat bekerja bersama-sama secara efektif dan maksimal. Nilai inti ini juga menjabarkan bahwa tujuan organisasi harus sesuai dengan kemampuan karyawannya sehingga dapat tercapai tujuan organisasi (kesempurnaa). Karakteristik dalam "Requisite Organization" adalah:

- Tantangan pekerjaan sesuai dengan kemampuan individu

- Rasa saling memiliki satu sama lain yang kuat

- Kesetiaan dan kepercayaan

- Pelayanan terbaik dengan biaya minimum

- Penetapan target dan parameter usaha yang jelas

- Lakukan apa yang harus dilakukan untuk tercapainya kesuksesan.

- Pihak yang berwenang bertanggung jawab atas hasil yang dicapai

- Keadilan dan konsistensi

- Memiliki saluran komunikasi terbuka

\section{The Three Hands (Tiga Tangan)}

Nah, Filosofi ini menggambarkan bahwa dalam bekerja sama secara bersamaan (w,w,w) ketiga pihak dapat menjalin hubungan yang saling menguntungkan. Bagi bisnis Sampoerna, representasi dari tiga pihak tersebut dapat diartikan sebagai mitra bisnis,organisasi, dan pelanggan. Filosofi dibagi menjadi empat nilai, yaitu:

1. Teamwork \& Flexibility (Kerjasama dan Fleksibilitas)

Dalam bisnis diperlukan kerjasama antar karyawan, atasan, dan keduanya. Meskipun terdengar mudah, namun dibutuhkan sikap untuk tetap mementingkan kepentingan bersama dibandingkan kepentingan pribadi. Karakteristik dalam "Teamwork \& Flexibility” adalah:

- "Kita" bukan "Saya"

- Kita semua menentukan kesuksesan organisasi dan berbagi tanggung jawab atas kegagalan

- Satu kesatuan akan lebih baik daripada gabungan dari berbagai bagian

- Musyawarah demi tercapainya suatu kesepakatan

- Bersedia untuk ditugaskan kembali guna mencapai tujuan organisasi maupun pengembangan individu (kawryawan)

2. Respect (Sikap Menghormati) Perilaku karyawan/pegawai saling menghormati baik di dalam atau di luar organisasi. Dengan sikap ini, kita diharapkan mampu untuk menghargai setiap orang dalam organisasi dengan tetap memperhatikan chain of command. Karakteristik sikap menghargai adalah:

- Memperlakukan orang lain dengan penghargaan \& rasa homat

- Tidak mentolerir adanya diskriminasi dalam bentuk apapun

- Mencari solusi terbaik (win/win) dalam segala permasalahan

- Menghargai budaya dan kebiasaan lokal

- Memberikan kontribusi kepada masyarakat

- Membangun bangsa 
3. Integrity \& Ethics (Integritas dan Etika) Integritas dapat diartikan sepagai konsistensi antara nilai yang dianut, tindakan yang dilakukan dan hasil yang dicapai. Integritas adalah apa yang menyediakan nilai kehidupan dari dalam diri untuk mengubah kesadaran ke dalam tindakan. Bila integritas dilengkapi dengan panduan etika yang unggul dan konsisten, maka saat ada ujian dari luar diri, diri akan memiliki kekuatan untuk membangkitkan keberanian agar memenangkan integritas pribadi dari ujian realitas sosial, politik, dan ekonomi kepentingan. Integritas dan etika dapat dilihat melalui karakteristik sebagai berikut:

- Melakukan hal yang benar

- Jujur dalam pemikiran dan tindakan

- Tidak mementingkan kepentingan pribadi

- Etos kerja yang kuat

- Memberi pendapat yang bersifat membangun

- Kesetiaan pada organisasi

- Kepatuhan terhadap hukum

- Menjadi perusahaan yang bertanggung jawab sebagai bagian dari masyarakat

- Obyektif dan jujur dalam operasional bisnis dan berinteraksi dengan orang lain

- Menciptakan rasa saling percaya dan keyakinan satu sama lain

4. Community (Membangun Komunitas)Komunitas merupakan salah satu stakeholder dari perusahaan yangakan menentukan mau kemana arah bisnis jangka panjang perusahaan. Memperoleh keuntungan adalah bukan salah satu tujuan perusahaan, tapi juga memberikan nilai kepada masyarakat sekitar dengan cara:

- Menjadi individu masyarakat yang baik dan organisasi yang bertanggungjawab

- Berkomitmen dalam membangun bangsa

○

Menjadi contoh bagi orang lain

\section{KESIMPULAN DAN SARAN}

\section{Kesimpulan}

Secara umum bisa dikatakan bahwa PT Bank Sahabat Sampoerna, sudah mempunyai visi, misi, dan tujuan dalam membangun bisnis perusahaannya tersebut. Untuk tecapainya visi, misi, dan tujuan didasari oleh kode etik dan corporate culture dalam menjalankan bisnis perusahaannya tersebut.

Etika merupakan dasar moral yang berisi tentang tuntunan perilaku, sikap, dan tindakan yang berhubungan dengan suatu jenis kegiatan manusia. Dengan etika manusia akan mampu untuk bersikap kritis dan rasional dalam membentuk pendapatnya sendiri dan bertindak sesuai keinginan sendiri yang dapat dipertanggung jawabkan. Dengan etika manusia juga mampu membedakan perilaku dan tindakan yang baik atau yang buruk.

Etika dalam berbisnis ini juga bisa dilakukan dalam segala aspek, termasuk dalam mejalankan bisnis di dunia perbankan. Harus menjaga kepercayaan serta kerahasiaan nasabah adalah satu hal yang wajib untuk di taati oleh seluruh karyawan yang bekerja di PT Bank Sahabat Sampoerna. Dalam hal kerjasama sangat berpengaruh besar dalam perusahaan PT Bank Sahabat Sampoerna, baik di ruang lingkup mikro maupun makro. Ini adalah wujud investasi jangka panjang bagi seluruh elemen dalam bisnis ini.

Maka dari itu, etika dalam berbisnis ini sangat penting jika diterapkan di setiap lini perusahaan khususnya di PT Bank Sahabat Sampoerna.

\section{Saran}

Berdasarkan studi literature, penulis ingin menyampaikan agar adanya sadar diri di setiap pegawai atau karyawan untuk menerapkan etika dalam berbisnis ini agar tidak ada kecurangan, kebohongan, dan penipuan yang terjadi pada perusahaan tersebut dan perlu penerapan sanksi atau hukuman yang berat apabila ada pegawai atau karyawan yang melakukan pelanggaran, 
sehingga etika dalam berbisnis ini pun bisa berjalan dengan baik dan benar di perusahaan tersebut, apalagi untuk menjaga nama baik suatu perusahaan khususnya PT Bank Sahabat Sampoerna.

\section{DAFTAR PUSTAKA}

Ali, Hapzi. 2017. Kaihatu, T.S. 2006. Modul Perkuliahan: Business Ethic \& GCG; Infact and Implementation. Universitas Mercubuana.Jakarta

Ali, Hapzi. 2020. Modul Business Ethics \& GG Panduan Etika Bisnis Perusahaan. Universitas Mercu Buana.Jakarta.

Amran, S (2011). Etika dan hukum bisnis. Retrieved March 02, 2020, from http://digemesta.com/indo/ei=klrFU5_1PNWRuASr9oL4Bw\&usg=AFQjCNEhFwiPu GovTSci0eLaOCRGccwssQ\&bvm=bv.70810081,d.c2E/etika-dan-hukum-dalambisnis.pdf

Bank Sampoerna, 2020. https://www.banksampoerna.com/wpcontent/uploads/2018/08/EDITORIAL-SMALLEST-AR-SAMPOERNA-28-05-14web-version.pdf (Diakses 31 maret 2020)

Budaya perusahaan, 2020. https://www.banksampoerna.com/bank-sahabat-sampoerna/visimisi-dan-nilai-perusahaan/ (Diakses 31 maret 2020)

Keraf, A.S. (1998). Etika bisnis: tuntutan dan relevansinya. Yogyakarta: Kanisius.

Lowney, C. 2005. Heroic Leadership, Terjemahan oleh Taryadi, Jakarta: Gramedia

Lukviarman, N. 2004. Etika Bisnis Tak Berjalan di Indonesia: Ada Apa dalam Corporate Governance?, dalam jurnal Siasat Bisnis. No. 9 Vol. 2, hal 139 - 156.

Muslich. (2004). Etika Bisnis Islami. Yogyakarta: Ekonesia.

Syah, Hidayat. 2010.Pengantar Umum Metodologi Penelitian Pendidikan Pendekatan Verivikatif. Pekanbaru: Suska Pres

Velasquez, M.G (2005). Etika bisnis, konsep dan kasus edisi 5. Yogyakarta: Penerbit Andi. 